\title{
Ethno-Religious Factor and the Menace of Election Violence in Nigeria
}

\author{
Jibrin Ubale Yahaya, $\mathrm{PhD}$ \\ Department of Political Science, National Open University Nigeria (NOUN) \\ Musa Mohammed Bello (PhD in view) \\ Institute of Governance and Development Studies, Nasarawa State University, Keffi
}

\begin{abstract}
Elections in Nigeria have been characterized by high scale of electoral malpractices, money politics, electoral violence and the use of ethno-religious divide strategy by political elite in order to influence the majority votes, claimed and announced as authentic election winners, these phenomenon's has dominate Nigerian electoral process since the return of democracy in Nigeria during 1999, 2003, 2007, 2011 and 2015 elections. Electoral violence is one of the strategies employed by Nigerian politicians during electioneering period to win election by illegal and dubious means. Desperate challenges of democratic governance operations and poor attitude of our leaders in Nigeria whose fails to meet the public demand of protecting lives and property as well as citizens welfare provision, the power drunk politicians often sponsor unemployed youths and stark illiterates to carry out assaults on their perceived political opponents with a view to manipulating election results to their own advantage. Therefore, this paper discusses electoral violence in the context of religion and its implication for sustainable development. Since electoral violence has been the bane of political stability and development in Nigeria. The researcher has uses secondary source of data to reviewed various literature on the subject matter to investigate the problem of election violence connecting it with religious or ethnic factor differences and used Karl Marx's dialectical materialism theory on the discussion of the problems of election violence in Nigeria. This paper has made an in-depth analysis of electoral violence in Nigeria with particular focus on the Fourth Republic. The paper was of the view that right application of religious teaching, moral values is considered to be a veritable tool for ensuring violence free elections, which will guaranteed development of democracy in Nigeria.
\end{abstract}

Keywords: Electoral Violence, Electoral Security, Religious and Ethnic Difference

DOI: $10.7176 / \mathrm{JCSD} / 59-04$

Publication date:May $31^{\text {st }} 2020$

\section{Introduction}

Electoral process is expected to contribute towards democratic consolidation in any given society. Through elections, the electorates are provided with the ample opportunity to vote for the candidates and parties that will represent their varying interests. However, in many African countries such as Nigeria, the electoral process has brought about unwarranted political instability. Nigeria, with a population of about 200 million and abundant mineral resources is being widely touted as one of Africa's brightest prospects on the global stage.

Since the 1950s, electoral violence has been a major problem in Nigerian politics (Albert, 2007:132). This ugly development has led to several deaths and colossal loss of properties, both private and public, in different parts of the country. It is a major reason for the present crisis of development in the country. It should be noted that violence is not a one-off event but a continuum in the electoral process. Thus, we can talk of pre-election; during election, and post election violence. This paper is a religious analysis of the connection between electoral violence and sustainable national development. Electoral violence has been a catalyst for underdevelopment given the havoc it has wreaked. Considering the socio-ethical relevance of religion, the application of religious moral values during elections is expected to stem the tide of violence (Dzurgba, 2009:29). This becomes imperative given the fact that religion is usually a strong factor in the electoral process (Familusi, 2012:66).

\section{Statement of Problem}

On May 29, 1999, Nigerians heaved a sigh of relief after the military relinquished power to the democratically elected government led by President Olusegun Obasanjo, an ex-military ruler. From that time, Nigeria has enjoyed over 21 years of democratic rule albeit, with various episodes of violence ranging from the Niger Delta militancy to the Boko Haram Insurgency in some parts of Northern East Nigeria (Borno, Adamawa and Yobe), Kidnapping, army bandit in states like Zamfara, Katsina and some part of Kaduna State while herders and farmers clashes in the middle belt in places like Benue, Nasarawa and Plateau. The year 2015 served as the turning point in Nigeria's democracy as the main opposition party, the All Progressives Congress (APC) upstaged the erstwhile ruling party, People's Democratic Party (PDP) at the general elections. The major thrust of this paper shall be geared towards analyzing both the preelection and post-election violence at the Fourth Republic polls since from 1999 elections to 2015 election to analyze the problem and also suggest better ways of addressing the problems for Nigeria to have functional and free violence 
electoral process in Nigeria.

\section{Research Questions}

The paper has the following questions to ask:

i. What are factors the causes of election violence in Nigeria during Fourth Republic?

ii. Does election violence of Fourth Republic differ with the previous election violence in Nigeria?

iii. What are the ways to address the menace of election violence in Nigeria?

\section{Research Objectives}

The paper has the general objectives of investigating the menace of election violence in Nigeria with the following specific objectives:

i. $\quad$ To find out the factors that causes election violence in Nigeria during the Fourth Republic

ii. To evaluate the election violence of the Fourth Republic and the previous election violence in Nigeria

iii. To examine ways to address the problem of election violence in Nigeria.

\section{Research Methodology}

The paper has uses the secondary source of information by reviewing relevant literatures on subject matter to investigate the issue of election violence in Nigeria and suggesting various ways to resolve the menace of election violence in Nigeria.

\section{Conceptual Clarification \\ Elections}

Elections form the bedrock of a genuine democratic system. Osumah and Aghemelo (2010) see election as a process through which the people choose their leaders and indicate their policies and programme preference and consequently invest a government with authority to rule. Roberts and Edwards (1991) cited in Omotola (2007) view election as a method of selecting persons to fill certain public offices through choices made by the electorate; those citizens who are qualified to vote under the laws and procedures of the electoral system. Webster's Encyclopedic Dictionary (2006) defines election as

"the act or process of organizing systematic (s) election (permitting mass participation and method of choosing a person or persons by vote for a public office position in which state authority is exercised".

\section{Electoral Violence}

According to Albert (2007), electoral violence involves all forms of organized acts of threats aimed at intimidating, harming, blackmailing a political stakeholder or opponent before, during and after an election with an intention to determine, delay or influence a political process. Ogundiya and Baba (2005), see electoral violence as all sorts of riots, demonstrations, party clashes, political assassinations, looting, arson, thuggery, kidnapping spontaneous or not, which occur before, during and after elections. Fischer (2002) defines electoral violence (conflict) as any random or organized act that seeks to determine, delay, or otherwise influence an electoral process through threat, verbal intimidation, hate speech, disinformation, physical assault, forced "protection", blackmail, destruction of property, or assassination.

Similarly, Igbuzor (2010), sees electoral violence as:

Any act of violence perpetuated in the course of political activities including, pre, during and post election periods, and may include any of the following acts: thuggery, use of force to disrupt political meetings or voting at polling stations, or the use of dangerous weapons to intimidate voters and other electoral process or to cause bodily harm or injury to any person connected with electoral processes.

The above definitions are the hallmarks of electoral violence in Nigeria's fourth republic.

\section{Electoral Security}

Electoral Security is defined as "the process of protecting electoral stakeholders such as voters, candidates, poll workers, media, and observers, electoral information and campaign materials; electoral facilities such as polling stations and counting centre and electoral events such as campaign rallies against death, damage, or disruption of the electoral processes (USAID). Furthermore, Fischer (2010), defined electoral security as "the process of protecting electoral stakeholders, information, facilities or events.

\section{Theoretical Framework}

For the purpose of this discourse, this paper will rest on Karl Marx's dialectical materialism which gives vivid explanations on electoral violence in Nigeria. Karl Marx's dialectical materialism suits Nigeria's scenario. Abbas 
(2010) observed that dialectical materialism is premised on man's inherent motivations of economic pursuits and needs. Thus, man's fierce inclinations and struggles to acquire, control and maintain political power at all cost justify the choice of this theory. Therefore, the relations between the people in the production processes are symbiotically connected with the nature and direction of the political struggles to capture political power in order to determine economic factors. Furthermore, this assertion was supported by Dudley (1965 cited in Etannibi, 2004)

\section{Dudley said that:}

"The reality was that Nigerian politicians perceived politics and political office as investment and as an avenue for the acquisition of extra ordinary wealth (through corruption) which they think is not possible through other forms of legitimate vocation and enterprise. Thus, in Nigeria, the shortest cut to affluence is through politics. Politics means money and money means politics...to be a member of the government party means open Avenue to government patronage, contract deals and the like".

In a country where over 70 per cent of the population lives in extreme poverty, politics is seen as an escape route from poverty. This is worsened by the high level of corruption among public office holders in Nigeria. Over the years, Nigerian politicians and other public office holders have promoted ostentatious lifestyles not been mindful of the sufferings of the Nigerian masses. One of Nigeria's brightest political scientists, Claude Ake (1964) asserted that:

"Those who win state power can have all the wealth they want even without working, while those who lose the struggle for state power cannot have security in the wealth they have made even by hard work. The capture of state power inevitably becomes a matter of life and death. That is one reason why our politics is so intense, anarchic and violent".

Comparatively, it has been discovered that elected representatives of the people at the local, state and federal levels of government earn higher wages and allowances more than their counterparts in the developed countries. Hence, the struggle for political power through any means becomes inevitable in Nigeria's political space.

\section{Electoral Violence Prior to 1999}

Electoral violence in Nigeria is traceable to the First Republic especially during the 1964/65 elections. The dominant political parties in the first republic, namely; the Action Group (AG), the Northern People's Congress (NPC) and the National Council of Nigeria and Cameroons (NCNC) were ethnically based parties that wanted to maintain the wide followership they enjoyed from the regions were they emerged. AG was essentially the party for the Yoruba race, NCNC was regarded as Ibo party, while NPC was predominantly a Hausa/Fulani party. During the 1964/65 elections, politicians were involved in wide scale murder, kidnapping and arson. Also, there were gross irregularities in the conduct of the elections that precipitated the military to stage a coup that ended Nigeria's first democratic experiment.

Electoral violence reared its ugly head again during the highly controversial 1983 general elections. The elections were massively rigged for instance, in the then Oyo and Ondo states, the two Unity Party of Nigeria (UPN) controlled states were declared for the ruling National Party of Nigeria (NPN). The announcement led to the outbreak of violence (Babarinsa, 2002). The scandalous 1983 elections caused general apathy among Nigerians. It was not surprising when the military intervened by ousting President Shehu Shagari on December 31, 1983.

The June 12, 1993 election organized by then Military President, General Ibrahim Babangida was expected to break the jinx of Nigeria's political history. The campaign strategies; government's support, the enthusiasm of registered voters and the generality of Nigerians towards June 12, 1993 are yet to be surpassed. The election was supposed to put an end to the eventful regime of General Ibrahim Babangida and usher in a democratically elected government (Olowojolu, 2015). Two political parties were created namely, Social Democratic Party (SDP) and National Republican Convention (NRC). The June 12, 1993 was unique in the sense that the two political parties fielded two muslim candidates in the person of highly influential billionaire MKO Abiola and the affable Bashir Tofa. MKO Abiola, a Yoruba from Western Nigeria was the Presidential flag bearer for SDP while, Bashir Tofa, a native of old Northern city, Kano was the Presidential candidate of NRC (Olowojolu, 2015). Despite the choice of SDP in picking Alhaji Babagana Kingibe as running mate, Nigerians did not raise eyebrows on the muslimmuslim ticket of SDP. On the other hand, NRC picked Sylvester Ugoh, a Christian from Eastern Nigeria as Tofa's running mate. Throughout the electioneering period, religious and ethnic affiliations did not influence voting patterns of Nigerians. June 12, 1993 election widely believed to have been won by MKO Abiola remains the freest and fairest election in Nigeria's history. The hopes of many Nigerians were dashed when the military government annulled the presidential election. Shortly afterwards, nationwide protests, industrial strike action and civil disobedience engulfed the country. The post June 12 crisis led military ruler, General Babangida to abdicate his exalted position as head of state on August 27, 1993. General Babaginda hurriedly relinquished power to an unpopular Interim National Government (ING) headed by Chief Ernest Shonekan (Olowojolu, 2015). 
The Interim National Government was sacked by General Sani Abacha on November 17, 1993. In 1994, General Abacha arrested the acclaimed winner of June 12, 1993 election, MKO Abiola on the account of treason as Abiola declared himself the president elect. Abacha's authoritarian regime expired when the head of state died on June 8, 1998 under controversial circumstances. On June 7 1998, MKO Abiola died on what was supposed to be his date of release. The newly appointed military ruler, General Abdulsalami Abubakar promised to return Nigeria to civilian rule in 1999 (Olowojolu, 2015). Eventually, the military regime ushered in Nigeria into the fourth republic. On May 29, 1999, ex-military ruler, Chief Olusegun Obasanjo was sworn in as the President of Nigeria. It marked the beginning of a new era in Nigeria's history.

\section{Trends and Patterns of Electoral Violence in the Fourth Republic}

Nigeria's fourth republic has witnessed the conduct of general elections in 1999, 2003, 2007, 2011 and 2015 respectively. These elections have been deeply enmeshed in series of violence before, during and after the elections. The 1999 elections had minimal record of violence largely because the military supervised the electoral process that birthed the fourth republic.

The 2003 elections were conducted by President Olusegun Obasanjo's administration who was seeking his second tenure. The 2003 elections were characterized by manipulation, rigging, thuggery and the assassination of perceived political opponents. The ruling People's Democratic Party (PDP) swept the polls as it consolidated its hold on the Nigerian political landscape. After the completion of two terms as President, Obasanjo's administration conducted perhaps the worst election in Nigeria's history. Prior to the 2007 elections, the outgoing President Obasanjo asserted that the election was going to be a "do-or-die" for the ruling PDP. Animashaun , S (2008), argued that there were massive irregularities in the 2007 elections and it was characterized by inflation of voting figures, declaration of results where elections were never held or not conclusive, intimidation of voters as well as manipulation of the security services. Results of elections conducted in some were totally different from those announced in Abuja contrary to the provisions of the 2006 Electoral Act (TMG, 2007).

The Human Rights Watch (2007) noted that there were scores of political killings, bombings and armed clashes between rival political groups. The outcome of the 2007 elections generated a lot of controversies and wide spread condemnation from both the local and international observers. The winner of the presidential election, late Umaru Musa Yaradua admitted that the electoral process in 2007 was highly fraudulent. Shortly after assuming office as the Executive President, Yaradua instituted an Electoral Reform Committee headed by Justice Uwais with a view towards correcting the ills in Nigeria's electoral system. Some of the recommendations of the Electoral Reform Committee were included in the amended Electoral Act. It is also on record that Yaradua's administration promoted non-interference in the judiciary. This was evident in the various judgements dispensed at both the Tribunal and Appeal courts over electoral disputes. Gubernatorial elections in states such as Ekiti, Osun, Edo and Ondo that were initially declared to have been won by PDP were upturned in favour of Action Congress of Nigeria (ACN) and Labour Party (LP) respectively (Aniekwe, et al, 2011).

The 2011 general elections were adjudged by many observers as the most credible election organized by the Independent National Electoral Commission (INEC) since 1999. For example, Terence McCulley, U.S. Ambassador to Nigeria praised the National Assembly election as the first-ever 'credible, transparent, free and fair general election' in Nigeria, and declared that it provided a 'historic opportunity for Nigeria to consolidate its democracy and further expand its voice on the world stage' (Agbambu and Ajayi, 2011). In the same vein, EU Election Observation Mission to Nigeria said 'the 2011 general elections marked an important step towards strengthening democratic elections in Nigeria, but challenges remain' (EU EOM, 2011).

Prior to the presidential polls, some Northern politicians including Adamu Ciroma, Iyorchia Ayu, Lawal Kaita, Bello Kirfi, Yahaya Kwande, and Bashir Yusuf Ibrahim wrote a letter to the PDP National Chairman on 17 September 2010 requesting the party leadership to restrain President Goodluck Jonathan from contesting the 2011 elections under the party's platform. The group argued that eight-year, two-term presidency ceded to the North in line with the PDP, which began with former President Umaru Musa Yar'Adua in 2007, must continue through another Northerner following Yar'Adua's death. The group warned that the failure of the ruling PDP to apply the principle of zoning would threaten the stability of Nigeria, saying; 'we are extremely worried that our party's failure to deliver justice in this matter (power-shift to the North) may ignite a series of events, the scope of magnitude of which we can neither proximate nor contain' (Abdallah, 2010, Obia, 2010). Inflammatory messages sent through the social media worsened the tensions created by religious and ethnic campaigning by supporters of President Jonathan and Muhammudu Buhari (Harwood and Campbell, 2010).

The Northern states of the country were thrown into chaos and anarchy after Dr. Goodluck Jonathan was declared the winner of the 2011 presidential election. Human Rights Watch (2011) reported that about 800 lives were lost as a result of the post election violence. Similarly, the Human Rights Watch (2011) claimed that more than 65,000 people were displaced after the 2011 post election violence. The Nigerian Red Cross Society released a slightly lower figure indicating that the violence displaced 48,000 persons in 12 states (Omenazu , 2011).

In the run up to the 2015 elections, the security challenges had become worrisome most especially in Northern 
Nigeria and Abuja the Federal Capital Territory. This is largely due to the meteoric rise in the Boko Haram Insurgency. The CLEEN Foundation Security Threat Assessment published in March 2015 found that 15 states were on red alert level. The National Human Rights Commission (NHRC) in its Pre-Election Report stated that at least 58 persons have been killed even before the conduct of 2015 general elections (CLEEN, 2015). There were changes in the political configuration of the country as could be seen in the formation of a mega opposition party, the All Progressives Congress (APC). Formed in 2013, APC was the amalgamation of the Congress for Progressive Change (CPC); the Action Congress of Nigeria (ACN); the All Nigeria People's Party (ANPP) and a faction of All Progressive Grand Alliance (APGA). Former military ruler, General Muhammudu Buhari (retd) was picked as the presidential flag bearer for APC. On the other hand, the PDP which has dominated Nigeria's political space since 1999 chose the incumbent president, Dr. Goodluck Jonathan as the presidential candidate. Prior to the 2015 polls, PDP suffered setbacks due to the mass exodus of key political players to APC. Jonathan who hails from the Ijaw ethnic group in the South-South region was perceived as the candidate of the South East and South-South of Nigeria. New measures were introduced with the view towards curbing electoral fraud and electoral violence during the 2015 general elections.

The Independent National Electoral Commission (INEC) under the leadership of Prof Attahiru Jega introduced the use of Card Readers and Permanent Voters Card (PVC) for the upcoming 2015 general elections. The technology of the Card Reader system has ensured credible elections in Ghana, Kenya and Sierra Leone (Vanguard, February 25, 2015). According to INEC, there were 66 reports of violent incidence all across the country. The violence were recorded in Rivers State (16 incidents); Ondo (8); Cross Rivers (6); Ebonyi (6); Akwa Ibom (5); Bayelsa (4); Lagos and Kaduna (3 each); Jigawa, Enugu, Ekiti (2 each); Katsina, Kogi, Plateau, Abia, Imo, Kano and Ogun (one each) (Vanguard, April 12, 2015). The European Union Election Observation Mission reported that about 30 people were killed on April 11, 2015 Election Day as a result of inter-party clashes and attacks on election sites (EU EOM, 2015).

The roles of some stakeholders and the international community in ensuring a peaceful election cannot be overemphasized. A former Minister of Foreign Affairs, Prof. Bolaji Akinyemi appealed to the major contestants of the presidential election to sign a Memorandum of Understanding (MOU) that will commit them to control their supporters against violence after the 2015 general elections (Punch, December 22, 2014). Similarly, the National Peace Committee for the 2015 General Elections led by former military ruler, General Abdulsalami Abubakar (retd) facilitated peace accord between General Buhari (retd) and President Jonathan (Punch, March 26, 2015). Concerned that Nigeria could burst into flames, America's Secretary of State, John Kerry flew to Lagos to discuss about the 2015 elections with President Jonathan and General Buhari (retd) respectively (Gordon, 2015).

Overall, the 2015 general elections were adjudged to be quite successful and more credible than every other election since the commencement of the fourth republic. The APC made history at the 2015 polls by becoming the first opposition party to defeat the ruling party in Nigeria. Thus, former military dictator, Gen. Muhammudu Buhari (retd) who had previously contested for the presidency in 2003, 2007 and 2011 upstaged the incumbent president, Dr. Goodluck Ebele Jonathan. The finest hour during the general polls was the noble character displayed by erstwhile President Jonathan when he accepted his defeat and ensured a smooth transition process that ushered in Buhari's administration on May 29, 2015.

\section{Rational Behind Electoral Violence in Nigeria}

Scholars have identified electoral violence as a variant of electoral malpractices. One reason for electoral malpractices is the attractiveness of politics owing to the luxury that is attached to political offices. It follows that people want to attain power at all costs. Consequently, the electoral process is usually marred with violence. In Dzurgba's (2003:51) submission, there is a view that 'politics is food'. In this sense, food means the type of life lived by politicians, which set them apart from the rest of the people. Invariably, this type of life is coveted by many people. Elections have become investments, and like any business outfit, people invest with the hope of reaping dividends. Odey (2003:12) also believes "that leadership in Nigeria has become huge investment and a life insurance where one has to engage in many abnormal things to be secure in perpetuity." Godfathers now triumph in politics because they have invested so much in it. Obaji opines that godfathers aim at political and economic control. They look at the entire political set up as a huge business empire from where endless profit must be made (Obaji, 2006:35). Oloruntimehin's (2012:13) conclusion on this scenario is that many state actors have been obsessed with building a political system where institutions and official responsibilities are converted to personal gains. For these actors, the main concern is to sustain a prebendal state in which government is run as an eatery. Associated with this is the notion that politics is war. Thus, political competition has become a battle in which enemies are to be defeated or wiped out completely. Dzurgba (2003:51) asserts further that:

Each contestant adopts appropriate strategies, tactics and maneuvers to ensure a great victory over his rivals. He counter-accounts his enemies who have been on the offensive and have fired several shots. Thus, a candidate who wins an election is a victor in a political war. So contestants have to mobilize their supporters so as to be able to demolish the strong resistance of their enemies in order to capture all available seats in a legislative assembly. 
Because politics is viewed in terms of war, it has been militarized, that hostility, aggression and violence have been taken to normal aspects of politics.

The word, 'capture' as used in the above quotation implies war. It is not surprising that politicians often boast that they would capture state presently ruled by their opponents. Governor Rauf Aregbesola of Osun State said at the 2014 convocation lecture of the University of Ibadan, Nigeria that the threat to capture states is a declaration of war on citizens and a misuse of language because in a democracy, elections are to be won, and seats, constituencies and states are not to be captured. Since politics is taken to be analogous to war, politicians prepare for, execute and react to elections violently. Lending credence to this, Oloruntimehin (2012:16) is unequivocal that "since 1999, electioneering has been conducted as war to be won at all cost ('do or die') to maintain a cabal that operates as an oligopoly, whose main concern is to run the Nigerian State as its estate". It is a common practice for private individual to import arms in preparatory to elections. When political thugs are supplied with arms during elections, such weapons become their property. In the spirit of impunity that is characteristic of Nigeria, arms and ammunitions have on several occasions been found in the houses of politicians with no legal action taken. Preparing for elections like wars also manifests during campaign as uncomplimentary remarks are made about opponents. The wife of former President Jonathan was quoted to have said that General Buhari is brain dead and that people should stone whoever says change, which is the slogan of the All Progressives Congress. There is obviously lack of political culture among Nigerian politicians. This is why they believe that every election must be won. It is almost impossible to hold elections that losers can accept without resorting to the courts or the streets in violent protest.

Much of the cases of violence are products of rigging or attempt to rig (Abogunrin, 1999). The issue of rigging is complex as every political party complains of rigging. However, experience has shown that virtually all contestants want to rig where possible. Consequently, whoever is out-rigged takes to violence. In 1983, violence broke out in the old Oyo State because of the provocative statement made by Chief Bola Ige, who believed that he was rigged out by the federal government headed by Alhaji Shehu Shagari. Conducting a free, fair and credible election in Nigeria has almost been taken to the realm of impossibility. As Oyeleye (2016:9) asks: "Which of our democracies has not been characterized by subversion or distortion? Which of our elections has ever been free of rigging, ballot snatching, ballot box stuffing,...specious legalism and other forms of irregularities?" Where the foregoing prevails, violence may be logically expected.

Lucrative nature of politics in Nigeria engenders lust for power, sit tight syndrome or tenacity of office. A case of paradox is obvious. Someone wants to grab power at all costs; another one wants to remain in office. Corroborating this, Odey (2003:12) says that "No Nigerian who has tasted the trappings of office has ever left them without fierce and often violent pressure, while those who aspire to be there spare nobody and nothing on their way." One cannot but expect violence to occur in this situation. It was obvious during the 2015 elections that the All Progressives Congress wanted to win in all states, while the People Democratic Party did not want to lose any. The violence that took place in River and Akwa Ibom states lend credence to this. Although the results of the elections were challenged up to the Supreme Court, the petitioner could not legally prove their cases beyond a reasonable doubt. In his reaction to the affirmation of Nyesom Wike of Rivers State, a constitutional lawyer, Itse Sagay, said the former became a governor over dead bodies. It is not only Wike who got to power through violence as there was no state where deaths were not recorded. Similar to this is the fact that winners have always taken all and losers have always lost all (Familusi, 2008:117). Therefore, opponents are excluded while forming cabinet and when appointments into boards and agencies are made. Winners are rarely magnanimous to form a broad based government. Few attempts made so far did not reflect the spirit of all inclusive government. Hence, they did not achieve the expected result. In Oyo State, the alliance between the Action Congress of Nigeria and the Accord Party in 2011, and the government of national unity formed by the Yar'adua's administration did not see the light of the day. Even the All Progressives Congress, which is an amalgam of four political parties still experiences internal bickering over appointments.

Dissemination of information is a critical aspect of the electoral process because of the need to keep people informed. The political reporter should have an indepth understanding of the electoral law of his country and be in touch with the electoral body. Since politicians and their parties are trying to gain the attention of the public, electoral reports are expected to be presented without being sensational and judgmental (Ganiyu, 2004:102). However, this is not the case in Nigeria as many media practitioners are paid to present positive report about politicians to the public, while those who are not in their good book are not given fair treatment. Inflammatory statements about the opposition through the mass media and campaign of calumny have always resulted in violence. Instances are the documentaries on General Muhammad Buhari and Senator Bola Ahmed Tinubu aired by African Independent Television (AIT). Also, there is usually inconsistency in the manner in which results are announced thereby misleading public. When results that are not authenticated are released, and after sometime, final results do not correlate with the previous one, violence will be the result. It is possible that candidates who did not win have been declared winners by a media outfit and their supporters would have started celebrating the supposed victory; and the reality dawns on them that their candidates did not win; there could be a clash with the supporters 
of the officially declared winners.

Much has been said about poverty as a cause of social vices in Nigeria; electoral violence is not an exception. Olukunle (1986:29) and Akanmidu (1995:51) are unequivocal in their submission that morality cannot be preached in the atmosphere of poverty. The level of poverty in Africa and Nigeria in particular is alarming. This has forced people to devise means of survival. Most of those who foment trouble during election are unemployed youths and victims of poverty. It is ironic that politicians and their key supporters rarely participate in violence, while those who are both idle and hungry are readily available. In sum, electoral violence is not alien to Nigeria and it is a reason for political instability, underdevelopment and the elusive democratic consolidation.

\section{Electoral Violence in Religious Context}

Electoral violence is a variant of Machiavellianism, and an indication that morality has been removed from politics in Nigeria. Machiavelli believes that the essential thing in politics is to try to grab power by all means, fair or foul and having grabbed it, all means must be used to retain it (Omoregbe, 1998:128). Those who belong to this school of thought will not think of the imperative of morality in politics. Our submission is that morality is an essential ingredient in politics if any meaningful development is expected in Nigeria. Moreover, electoral violence is a negation of religious moral values. No religion preaches violence; involvement of practitioners notwithstanding. Therefore, one should expect a violence-free electoral process given the religious inclination of many stakeholders on the electoral process. The ethics of the three major religions in Nigeria: Christianity, Islam and African Traditional Religion will be used as our guide in analyzing electoral violence in Nigeria. The fact has been established that electoral violence is an offshoot of electoral malpractices. The position of Familusi (2010:103107) is that the three religions advocate credibility, decency and transparency at all stages of elections.

Sometimes, religious and ethnic organizations are also involved in political violence, for instance in Bauchi State, where 32 Christians were killed and 72 churches were burnt over presidential election results in April 2011. The attackers were mainly Hausa thugs encouraged by Muslim preachers, even if the official Islamic umbrella body in the North, Jama'atu Nasril Islam (JNI), claimed no responsibility for the violence. Kaduna and Plateau are also very much affected by such killings: most electoral incidents occur in LGAs with a mixed population of Hausa-Fulani Muslims and Christian natives. Nationwide, places of worship - churches, mosques, and templesare also targeted during political riots. This was the case in 51 (5.57\%) of 915 fatal incidents related to elections during the period 2006-2014, according to the Nigeria Watch database.

Peace is one of the cardinal virtues in Christianity (Shield, 2005:174). Therefore, Christians who are involved in electoral matters are expected to eschew violence or evil attitude toward other people. Both the old and new testaments condemn deliberate killing of human beings. It is only in the atmosphere of love that peace prevails. Love is the most fundamental aspect of values in Christian thought. It is demonstrated through kindness, gentleness, tolerance and peacefulness. On the other hand, anger, enmity or hatred are immoral practices, thus, they are detested. It imperative to note that Christianity as a religion preaches peace to all mankind. However, it is not silent about war and violence. Of course, so much has been said by scholars and theologians; and there is no consensus on what the attitude of a Christian should be. While some advocate pacifism, others opt for selective militarism. Origen and Tertullian, for instance, reject war, while Augustine and Thomas Aquinas hold that wars could be fought for some reasons, which are highlighted in the just war theory and permissibility of war as espoused by Aquinas and US Catholic Bishops (Robin Gill, 2014:261-312). Kunhiyop believes that the discourse is controversial given the divergent opinions expressed in respect of the biblical teaching. For instance, according to him, it can be said that Jesus was both in support and against war. On his advice to his disciples to buy a sword, he infers as follow:

Jesus is acknowledging that swords may be needed for self protection. When the authority provides no protection, it is appropriate to protect one. It would have been unwise to travel in the mountains where there were robbers and thieves without a sword, and it is right and proper to arm oneself in order to defend oneself, one's family and the weak. Advocating a non-violent response to oppression and injustice is not at odd with self-defense or defense of one's family or even one's church (Kunhiyop, 2008:119).

While one agrees that there are logical and justifiable reasons a Christian may be involved in war, fighting in the electoral process does not fall under any of the reasons (Shields 2004:182). The truth of the matter is that immorality cannot curb immorality. Therefore, whatever the reasons advanced for electoral violence, it cannot stand the test of Christian ethics. Not even provocation from political opponents should propel it.

In Islam, faithful Muslims are enjoined to be in peace with one another. Peacefulness, a prime virtue in Islam, means not harming others. All Muslims are expected to exhibit the spirit of neighbourliness, be tolerant and eschew aggression. As contained in the Hadith, Prophet Muhammed advocates the need to love and desist from anything that may lead to anarchy. The foregoing implies that violence is prohibited is Islam. Consequently, Muslims are duty bound not to engage in violence as such would be tantamount to disobedience to Allah (Katerrega ans Shenk, 1985: 158). 
Islam is understood as a religion of peace. Given this, violence must not have any part to play in it. The fact that there are some militant sects does not suggest that the religion is favorably disposed to violence. Readers should be reminded that many Muslims and Islamic organizations have openly dissociated themselves from Boko Haram insurgents because their activities are antithetical to Islam. In other words, even if a Muslim is involved in violence, it does not mean that the fellow is acting the script of Islam. Interestingly, nobody has come out openly to claim membership of Boko Haram. This perhaps explains why former president Goodluck Jonathan described them as faceless, hence his incapacitation to dialogue with them. As said by Archbishop Desmond Tutu, the problem is not faith but the faithful (News Perspectives Quarterly, 2010:68-71). Oftentimes, people mistake religion for practitioners, thus, Christianity is blamed for the misdemeanor of Christians.

Violence of any kind is also condemned in traditional African society. For example, among the Yoruba of South-western Nigeria, morality is codified in the word, 'Iwa' (character), which is the very factor that makes life pleasing to God and joyful for mankind (Oyeshile, 2004). It is expedient for human beings to exhibit good character and one expects that whoever possesses this attribute will refrain from electoral violence. African Traditional Religion also advocates harmony. It discourages discord and incongruous disposition. Harmonious life demonstrates contentment, patience, temperance, moderation, tolerance and seeking well-being of everybody (Akintola, 1999:157). These values are crucial to credible and violence-free elections.

As can be deduced from the analyses, religion is an agent of peace, and it emphasizes sanctity of lives, which are often lost to violence. The problem is with those who use religion to foment trouble. If the value of peace is imbibed by all participants in the electoral process, particularly those who have religious inclination, religion will be a veritable tool for achieving free, fair and credible elections, which have continued to be a mirage in the political history of Nigeria.

\section{Development Issues and Electoral Violence in Nigeria}

Electoral violence is the bane of development in Nigeria considering the magnitude of its effects. Development in the context of this paper refers to a multidimensional process involving major changes in the social structures, popular attitudes and national institutions, as well as the acceleration of economic growth, the reduction of inequality and the eradication of poverty. At the centre of development is man, who is either a victim or beneficiary of policies or activities that have to do with development. Therefore, main indices of human development are life expectancy at birth, education attainment as measured by mean years of schooling and adult literacy as well as standard of living as measured by per capita income (Olaniyan and Lawanson, 2006:109). Also considered are conditions of infrastructures and institutions such as schools and hospital. It is no news that several lives have been lost to electoral violence in the political history of the country. Listing those who have been killed is not expedient as one would lose count. Life is precious and it is the only thing that human beings have in common no matter the status. Every individual rich or poor, young and old has one life and it is irreplaceable. Therefore, when a life is lost, the end of an era has come. The main argument is that those who have lost theirs to electoral violence had the potential to contribute to the development of the country in terms of manpower. It should be noted that much of political killing is a variant of electoral violence, which takes place at different levels. Therefore, political violence cannot be discussed in isolation from electoral violence. To show the extent of killings during the 2007 elections, corpses were brought to election tribunal in Osun State. Similarly, the 2011 electoral violence in the north led to widespread murder including the killing of electoral officers and thirteen NYSC members in Bauchi and attempted attacks on the palaces of Sultan of Sokoto and Emir of Zaria (Osuntokun, 2012:43). Okoosi-Simbine (2004:95-96) confirms the ubiquitous loss of lives in electoral violence as follows:

Civilian politics since 1999 and more so, the preparation towards the 2003 elections were characterized by acid attack and political assassinations (for instance, the killing of Chief Bola Ige in Oyo State, Lawyer and Mrs. Igwe in Anambra State, Chief Marshall Harry in River State and so on, with authorities seemingly incapable of finding those responsible not to talk of bringing them to book). Politically instigated inter-communal, ethnic and religious conflicts (resulting in the killing for instance, of Maimuna Katai, Commissioner for Women Affairs in Nassarawa State reportedly during a dispute over polling in her constituency).

As noted by Salau (2015), the foregoing loss of lives will always impel retrogression.

A research conducted by the Nigeria Watch revealed that between June 2006 and May 2014, there were about 915 cases of election violence resulting in about 3934 deaths. A further breakdown of the figures showed that the North Central geopolitical zone had the highest casualties among the country's six zones, recording 1463 deaths. It was followed by the North West with 911 deaths and the South-south with 644 deaths. The South East had the least figure of 152 deaths, the North East and South West recorded 319 and 386 deaths respectively.

Apart from loss of lives, properties, both private and public, that have been lost to electoral violence cannot be quantified and this has spelt doom on overall development. For example, if structures belonging to the government are destroyed, such will be replaced or rehabilitated with public money. It follows that many other 
things that could aid development will go for it. In some cases, property once destroyed may not be rebuilt especially if owned by individuals whose sources of income have been destroyed. One could imagine the experience of an entrepreneur, who is a victim of violence. What happens to his investments and employees when his business or businesses crumble? Among the casualties of 1983 post election violence was the first indigenous publisher, Honourable Albert Olaiya Fagbamigbe. He was murdered two weeks after his 58th birthday (http://www.sharpedgenews.com/index.php).

Violence of any kind breeds ecological problems which in turn could constitute social, economic and health hazard. The relic of the violence that followed 1983 elections are still visible in some parts of the South-western Nigeria, while many of the places destroyed in 2011 remain inhabitable and many farmlands become useless for cultivation (Onwuaroh, 2014:44).

Economic retrogression has always arisen from violence in that it is not possible for citizens to transact their businesses efficiently where/when peace is elusive. Of course, electoral violence portends danger for foreign investors who may wish to establish business in Nigeria. (http://www.vanguardngr.com). As new investors will not come, existing ones may not have choice but to leave for safety. Bello (2015) confirms that the anxiety over the outcome of the 2015 elections exacerbated economic and political risks in the country, resulting in foreign investors pulling N846.53billion from the Nigerian Stock Exchange (NSE) in 2014. The figure represents 65.7 per cent increase on the N510.78 billion foreign portfolio investment outflow from the stock market in the corresponding period of 2013 (http://www.vanguardngr.com/ http://leadership.ng/news). Lending credence to this, Daniel (2015:30) is emphatic that: "as a result of economic losses caused by electoral violence in Nigeria, political investors within and outside the country have been discouraged because it is widely believed that a country without a stable political system will not be able to guarantee the safety of their investors and investment."

Still on development, the image of the country in the international community is at stake. Emphasizing this, Alanamu says that:

This becomes obvious when examined in the light of the value of transformation, which has taken place as a result of the end of the cold war and emergence of a New World Order. This development emphasizes respect for human rights, which is an integral value of democracy. As such, failure to effectively protect human rights may create another round of international image for Nigeria.

Image problem in the context of this piece is an issue in development. Political instability, which has been experienced in Nigeria as a result of electoral violence, has wreaked much havoc in terms of development. The episodes of 1965, 1983 and 1993 are still fresh in the memories of Nigerians. One of the reasons petitioners usually give for challenging the results of elections is violence and many elections have been invalidated consequent upon this. When this happens, rerun elections are ordered. Such elections like normal elections involve money. Apart from money released by the government to the electoral commission, states concerned may not have choice but to fund the elections with money that would have been used for developmental projects. The INEC Chairman, Mahmud Yakubu, while presenting INEC's 2015/2016 budget before the House of Representatives Committee on Electoral Matters said N10b would be required to fund rerun elections in eight states of the federation. (https://www.today.ng/politics). This is no cheering news at this time when the government at all levels find it difficult to pay workers and pensioners as and when due. Still on the economic dimension of electoral violence, Salau (2016) has this to say:

Under a subhead of the capital side of the 2016 Appropriation Bill is the sum of N2.5 billion for rehabilitation of public properties and places of worship that were damaged during the 2011 election as a result of violence and civil disturbances. Ironically, five years after the violence and civil disturbances that followed that election; those who suffered one loss or the other are still being compensated.

As established in this section, electoral violence is a major factor responsible for underdevelopment. This could be summarized in the words of Arazeem (2005:157) that:

Violence, regardless of its nature tends to slow down development because development can only take place under a peaceful atmosphere. As it would be difficult for a blind man to see even in the broad daylight, so it would be difficult for a nation to experience any form of growth or development where there is no relative peace. That is, no amount of national unity and social integration can be achieved under any kind of unstable atmosphere.

\section{Consequences of Election Violence in Nigeria}

An analysis of the Nigeria Watch database for the period between June 2006 and May 2014 revealed 915 fatal incidents related to elections. The research did not include terrorist attacks by Islamic or militant groups with religious, social, or economic undertones, but it did study the involvement of such groups in political violence. A total of 3,934 deaths were recorded from these 915 incidents, with the highest prevalence in Plateau State and the lowest in Jigawa State. As the main stakeholders of electoral processes, political parties are directly involved 
in electoral violence.

A spatial analysis of the Nigeria Watch database shows that the bloodiest geopolitical zone is the Middle Belt, with 1,463 deaths. The region is characterized by pre-existing ethno-religious tensions, just as in the North-West (911 deaths). The North-East (319 "political deaths") is affected mainly by the Boko Haram insurgency, which is not covered by this study. So-called godfatherism affects more the South-West (386 deaths) and the South-South (644). The South-East also witnesses political thuggery but records the lowest occurrence of deaths from electoral processes (152). Most electoral violence in northern Nigeria was found to have an ethno-religious background, whereas the southern part of the country is more affected by the high prevalence of criminal gangs. Security forces are also key catalysts in electoral violence, as they often exacerbate cases where they intervene.

Political violence is the only cyclical violence the Nigeria Watch project could identify in Nigeria, and this violence occurred during the polls of April 2007 and April 2011 (Pérouse de Montclos 2011: 3). Indeed, according to the CLEEN Foundation, violence has been "a feature of the country's electoral process since the colonial era" (Alemka, 2011).

In 1983, for instance, post-election violence followed the declared landslide victory of the National Party of Nigeria (NPN) in Oyo and Ondo states, which were the stronghold of the Unity Party of Nigeria (UPN). During the planned transition from military rule to democracy, General Ibrahim Badamasi Babangida and his successor, Sani Abacha, also witnessed demonstrations and bombings when supporters of the National Democratic Coalition (NADECO) called on the Government to step down in favour of the winner of the 12 June 1993 election, late Chief MKO Abiola. With the return to a civilian regime in 1999, Nigerians went to the polls again, though this time with relatively low violence before and after the vote. Yet the elections, which brought retired General Olusegun Obasanjo to power, were blighted by widespread fraud. Likewise in 2003, the election was characterized by violence, corruption, and the falsification of results, according to the Transition Monitoring Group (TMG), a coalition of 170 NGOs in Nigeria. Similarly, in 2007, foreign and national monitors observed violence, corruption, fraud, and manipulation. The 2011 round, on the other hand, was reported to have been well-run relative to past elections. Nonetheless, "violence claimed 800 lives over three days in Northern Nigeria and displaced 65,000 people, making the elections the most violent in Nigeria's history" (Bekoe 2011).

Table 1: Ranking of states from highest to lowest prevalence of political/electoral fatalities (2006-2014)

\begin{tabular}{|c|c|c|}
\hline RANKING & STATE & NUMBER OF FATALITIES \\
\hline 1 & PLATEAU & 850 \\
\hline 2 & KADUNA & 653 \\
\hline 3 & NASARAWA & 258 \\
\hline 4 & RIVERS & 181 \\
\hline 5 & KANO & 152 \\
\hline 6 & DELTA & 142 \\
\hline 7 & $\mathrm{OYO}$ & 110 \\
\hline 8 & BENUE & 109 \\
\hline 9 & KOGI & 107 \\
\hline 10 & BAYELSA & 93 \\
\hline 11 & AKWA IBOM & 91 \\
\hline 12 & NIGER & 86 \\
\hline 13 & BORNO & 84 \\
\hline 14 & EDO & 83 \\
\hline 15 & LAGOS & 80 \\
\hline 16 & BAUCHI & 63 \\
\hline 17 & TARABA & 61 \\
\hline 18 & FCT & 59 \\
\hline 18 & OSUN & 59 \\
\hline 19 & ONDO & 55 \\
\hline 20 & CROSS RIVER & 54 \\
\hline 21 & KWARA & 53 \\
\hline 22 & OGUN & 51 \\
\hline 23 & ADAMAWA & 49 \\
\hline 24 & $\mathrm{IMO}$ & 45 \\
\hline 25 & ANAMBRA & 38 \\
\hline 26 & KATSINA & 37 \\
\hline
\end{tabular}




\begin{tabular}{|c|c|c|}
\hline RANKING & STATE & NUMBER OF FATALITIES \\
\hline 27 & GOMBE & 33 \\
\hline 28 & EKITI & 31 \\
\hline 29 & YOBE & 29 \\
\hline 30 & ZAMFARA & 25 \\
\hline 31 & ENUGU & 24 \\
\hline 32 & KEBBI & 23 \\
\hline 32 & ABIA & 23 \\
\hline 33 & EBONYI & 22 \\
\hline 34 & SOKOTO & 11 \\
\hline 35 & JIGAWA & 10 \\
\hline & TOTAL & $\mathbf{3 9 3 4}$ \\
\hline
\end{tabular}

Source: TMG , 2015

FIGURE 1: NUMBER OF FATALITIES FROM ELECTORAL VIOLENCE PER STATE AND PER ZONE (JUNE 2006 - MAY 2014)
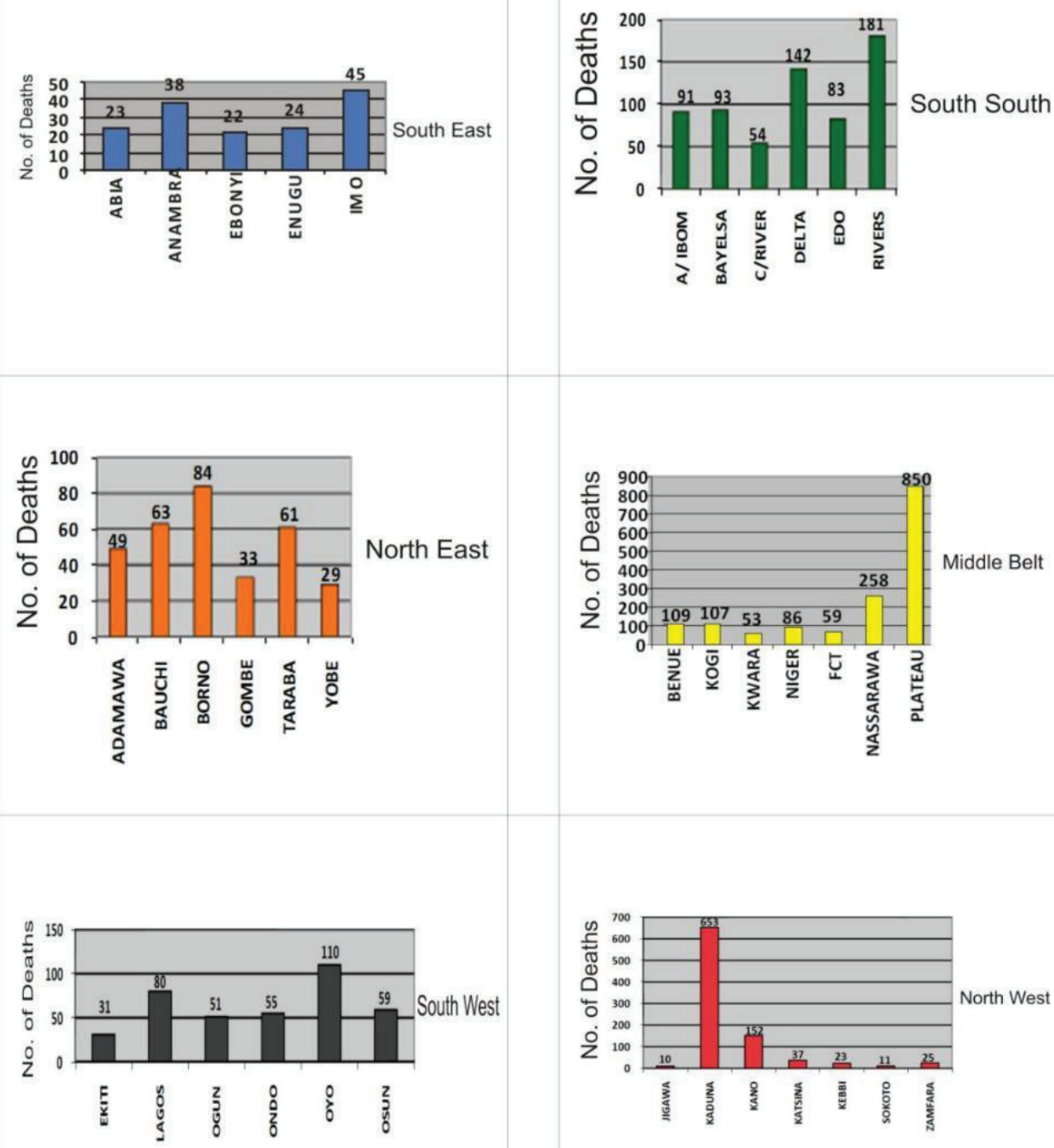

Prospects for Political Stability in Nigeria

The problem of political stability in Nigeria is the dilemma of how to secure enduring, legitimate political order in Nigeria has long been the focus of much philosophical discourse. Thomas Hobbes sees political stability as 
paramount because in its absence, there could be no security for either life or liberty, and thus man's existence could never be anything more than a chaotic, violent and bloody struggle for power.

Nigeria was in danger of becoming what the UN Secretary General has called "a failed State". The UNDP Human Development Report (1994)" predicting societal disintegration" as cited in a Canadian Security Intelligence Service Commentary No 66 cited Nigeria as a prime possibility, given the wide social and economic disparities between its states, noting they were among the worst in the world. And if Nigeria does crash into anarchy, it would take some of its West African neighboring countries with it - transforming the region into a global crisis zone. Structural constraints should not be neglected in any analysis of Nigeria; the way forward is to develop a special model for conflict resolution that suites Nigeria. Policies should be geared towards strengthening democracy, human rights development, the market economy, infrastructural development, provision of employment, conflict management and prevention of the local level, particularly in the country's hotspot areas, to ensure long lasting calm and to further stabilize the still fragile, three-tier federal system .

The pursuit of electoral victory at any cost is still a regular feature of the Nigerian political system. The "mustwin' attitude of political participants, coupled with a winner-takes-all political system in Nigeria, with its adversarial nature, usually engenders divisions and provides incentives for competitors to resort to court. This explains why systematic rigging of elections, bribery of voters, disenfranchisement of group and individuals, miscounting, non- counting of ballots, false tallying of votes, use of under-age, intimidation by opponents and of opponents, and the open employment of uniformed and civilian thugs to create fear and compliance have been the hallmark of elections in Nigeria. These events of the past were manifest in 2015 General Election. There is a limit to which the courts can be trusted to handle the issue of non acceptance of alternation in power, being a politically endemic problem largely due to the mindset of the political participants.

In tandem with the philosophical thoughts of Thomas Hobbes, a peace agreement was initiated for all the Presidential aspirants and their Party Chairmen in the 2015 General Election. Peace accord or agreement is a major aspect of conflict management that involves third party intervention. The third party acts as a mediator to the conflicting parties in attempt to deescalate and transform the conflict.

The violence that followed the 2011 presidential election in the country led to the death so many Nigerian and created tension and apprehension of possible insecurity in 2015 general election. To stem the tide of hostility which already had brewed, on January 14 2015, the Office of the National Security Adviser and the Special Adviser to the president on Inter-Party Affairs through a generous financial grant and support of donor agencies including United Nations Development Programme (UNDP), European Union (EU) and others organized a workshop on the 2015 general elections

The workshop with the theme: "2015 General Elections Sensitization Workshop on Non-Violence" had most

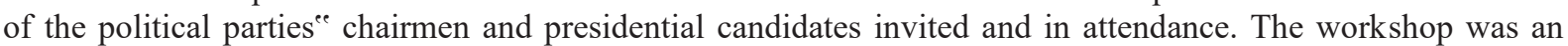
attempt to deescalate the raging conflict that was looming in the political space through reorientation of the political actors- political parties ${ }^{\text {ee }}$ leadership, candidates and other stakeholders. The 14 presidential candidates and their Chairmen as well as Chief Emeka Anyaoku signed the below declaration while Mr. Kofi Anna observed the proceedings.

We, the undersigned presidential candidates of the underlisted political parties contesting the general election of 2015, desirous of taking proactive measures to prevent electoral violence before, during and after the elections, anxious about the maintenance of a peaceful environment for the 2015 general election, reaffirming our commitment to the constitution of the Federal Republic of Nigeria, desirous of promoting the unity and corporate existence of Nigeria as an indivisible entity, determined to avoid any conduct or behaviour that will endanger the political stability and national security of Nigeria, determined to place national interest above personal and partisan concern, reaffirming our commitment to fully abide by all rules and regulations as laid down in the legal framework for elections in Nigeria hereby submit ourselves and our parties to the following:

1. To run issue based campaigns at national states and local government levels. In this, we pledge to refrain from campaigns that will involve religious sentiment, ethnic or tribal profiling, both by ourselves and all agents acting in our name.

2. To refrain from making or causing to make in our names or that of our parties any public statement, pronouncement, declaration or speeches that have the capacity to incite any form of violence before, during and after the elections.

3. To forcefully and publicly speak out against provocative utterances and oppose all act of electoral violence whether perpetuated by our supporters and, or opponents.

4. To commit ourselves and political parties to the monitoring of the adherence of this accord if necessary, by a national peace committee made up of respected statesmen and women, traditional and religious leaders.

5. All the institutions of government including INEC and security agencies must act and be seen to act with impartiality.

The initiators of the accord created a platform for the implementation, monitoring and mediation where in breach. Consequently, the National Peace Committee (NPC) with General Abdusalami Abubakar as Chairman and 
other eminent Nigerians as Members was created.

Despite this accord, there were still conflicts in different parts of the Country.

President Jonathan had called Muhammadu Buhari to congratulate him on his victory at exactly 5:15 p.m. local time on Monday, March 2015.

The phone call took place almost ten hours before the Independent National Electoral Commission (INEC) officially declared Buhari the winner with a total of 15,424,921 votes against 12,853,162 for Jonathan [30]. This historic call, couple with the conceding of victory speech by President Jonathan after the announcement of election results, to a large extent stemmed the violence that would have arisen. These actions deepened political stability

\section{Conclusion}

Electoral violence generally refers to violence that is directly or indirectly connected to protest against an election. Nigeria's post independence history is replete with accounts of incidents of electoral violence. In the contemporary world, elections have become the most accepted means of changing the government. Although history has shown that, it is usually difficult to hold elections that are completely free and fair. Consequently, we argued that elections, which in other climes are processes that bring about peaceful change of government, have not been conducted in Nigeria according to international best practices governing their conduct. We analyzed the historical trajectory of elections in Nigeria, electoral violence in Nigeria's $4^{\text {th }}$ republic, $1999-2015$, electoral violence and political instability, prognosis of 2015 general election and prospects for political stability. Finally, we made far reaching recommendation which amongst others includes the establishment of Election Offences Tribunals to try those who flout the Electoral Law by committing offences such as rigging, falsification of documents and election results, thuggery, etc. It is our hope that our suggestions if adhered to would set the stage for the conduct of violence-free elections which would engender political stability and place Nigeria in the echelon of powerful democracies in the world.

\section{Recommendations}

In order to salvage the nation from collapsing into precipice and engender political stability, we recommend the following:

1. Full autonomy for the Independent National Electoral Commission (INEC)

This autonomy would engender administrative efficiency and professionalism of the Body. Also, the appointment of INEC Chairman should reside in the people and not Mr. President. The people in this circumstance are the Legislature. The Constitution should be restructured to make the office elective through an electoral college that would be composed of Members of the National Assembly, State Houses of Assembly and all serving Judges of the Supreme and Appeal Courts in Nigeria.

2. Respect for rule of law.

3.The establishment of Election Offences Commission as suggested by the Justice Uwais Committee to try those who flout the Electoral Law by committing offences such as rigging, falsification of documents and election results, thuggery, etc be implemented.

Implementation of the report of the National Constitutional Conference, 2014

Setting up of alternative dispute resolution mechanism

4. Job creation for the large number of unemployed in country to get rid of higher level of criminality.

5. Government should create an extensive program of public education through various means that could reach large number of audience on the dangers of election violence and the benefit of election good leaders that can serve his peoples diligently.

\section{References}

Abbas, I.M. (2010). Election violence in Nigeria and the problem of democratic politics. Seminar Paper presented at the Department of Political Science, ABU Zaria on February 26.

Agbambu, C. and Ajayi, A. (2011), 'US Rates Nigeria’s Elections High, Says Country Made History with April Polls...' Nigerian Tribune (Ibadan), 29 April.

Alemika EEO. Clean foundation: Post - election violence in Nigeria.(Accessed July 2015)

Available:blogspot.com/2011/07/post-election-violence-in

Ake, C. (1964). 'The Political Question' in O. Oyediran (ed). Governance and Development in Nigeria: Essays in Honour of Professor B.J. Dudley. Ibadan. Oyediran Consult International

Albert, I.O. (2007). Reconceptualizing electoral violence in Nigeria, In I.O. Albert, D. Marco and V. Adetula (Eds). Perspectives on the 2003 Elections in Nigeria Abuja: IDASA and Sterling-Holding Publishers

Arazeem, A.A. 2005."Combating Political Violence in Nigeria: Issues, Prospects and Problems" Alanamu, A.S. (Ed.) Issues in Political Violence in Nigeria, Ilorin: Hamson Printing

CLEEN Foundation (2015). Electoral Violence Risks in the 2015 Gubernatorial Elections. A Policy Brief, Election Security Brief 012 
EU EOM (2011), EU Observation Mission to Nigeria: Final Report on the 2011 General Elections: Abuja: European Union.

European Union Election Observation Mission (2015) Final Report on General Elections 28 March and 11 April 2015.

Familusi, O.O. 2008 “A Religious Assessment of the Electoral Process and Moral Responsibility

Ibadan, Oyo State,1999-2003” Ph.d Thesis University of Ibadan, Nigeria.

Fischer, J. (2002). Electoral conflict and violence IFES. Washington, D.C.

Fischer, J. (2010). "Electoral Conflict and Violence: A Strategy for Study and Prevention". Washington, D.C: International Foundation for Election Systems.

Gordon, M. (2015), Kerry Meets With Nigerian Leaders to Encourage Peaceful Election, The New York Times, January 25.

Ganiyu, M.( 2004) The Reporter's Companion: A Complete Guide to News Reporting and Writing. Ibadan: Emgic Books.

Harwood, A. and Campbell, J. (2010), 'Opinion: Text Messaging as a Weapon in Nigeria'. Global Post, September 22.http://www.globalpost.com/dispatch/africa/100916/text-messaging-weapon-northern-nigeria

Human Rights Watch. (2007). Election or "Selection"? Human rights abuse and threats to free and fair elections in Nigeria. New York.

Human Rights Watch. (2011). Nigeria: Post-Election Violence Killed 800. Washington DC: Human Rights Watch http://www.hrw.org/news/2011/05/16/nigeria-post-election-violence-killed-800.

Human Rights Watch. Election or "Selection"?. Human rights abuse and threats to free and fair elections in Nigeria. New York; 2007. (Accessed June 20, 2015)Available:https://www.hrw.org/legacy/back grounder/africa/nigeria0407/3.htm

INEC's website, Map of 2011 Presidential Election Map. See http://www.inecnigeria.org

Igbuzor O. Electoral violence in Nigeria. Asaba, Action Aid Nigeria; 2010.

Olowojolu, O. (2015), Ethnicity and Religion: Key Indicators in Nigeria's Electoral System, International Conference on Social Sciences, Istanbul, Turkey.

Odey, J.O. (2003) This Madness called Election 2003, Enugu: Snaap Press Limited

Okoosi-Simbine, A.T. 2004. "The Impact of More parties on the Democratic Project" Saliu H.A. (ed) Nigeria Under Democratic Rule 1999-2003, vol. 1, Ibadan, University Press, 85-98

Oloruntimehin, B.O 20012. "Introduction : Weighing Isuuses of Governance Through Elections in Hiatorical Perspective" Oloruntimehin, B.O. (Ed.) Nigerian Elections in Historical Perspective, Ibadan NAL., pp. 1220.

Olukunle, A.O. 1986. "Ethical Revolution: The Newest Craze in Town", in S.O. Abogunrin (ed) Religion and Ethics in Nigeria, Ibadan Dayst. 